\title{
Terrestrial planarians (Platyhelminthes, Tricladida, Terricola) from the Iberian peninsula: first records of the family Rhynchodemidae, with the description of a new Microplana species
}

\author{
Eduardo Mateos ${ }^{1}$, Gonzalo Giribet ${ }^{1,2}$ \& Salvador Carranza ${ }^{3}$ \\ ${ }^{1}$ Departament de Biologia Animal, Universitat de Barcelona, Avinguda Diagonal 645, 0807I Barcelona, \\ Spain; ${ }^{2}$ Present address: Department of Invertebrates, American Museum of Natural History, Central Park \\ West at 79th Street, New York, New York 10024-5192, USA; ${ }^{3}$ Departament de Genètica, Universitat de \\ Barcelona, Avinguda Diagonal 645, 08071 Barcelona, Spain (corresponding author: S. Carranza, \\ carranza@porthos.bio.ub.es)
}

Keywords: Microplana, Rhynchodemidae, Terricola, new species, ITS-1, molecular markers, Iberian peninsula

\begin{abstract}
The first records of terrestrial planarians belonging to the family Rhynchodemidae are reported for the Iberian Peninsula. A new endemic species from the Spanish Pyrenees, Microplana nana sp. nov, is described. The characteristic features of this species are: i) small size (8-10 mm) in adult individuals, ii) very long conical penis papilla and iii) absence of seminal vesicle, bursa copulatrix, genito-intestinal duct, and well-developed penial bulb. Moreover, the widespread common European land planarian Microplana terrestris (Müller, 1774) is reported for the first time from the Iberian Peninsula. The two species, $M$. nana sp. nov, and $\boldsymbol{M}$. terrestris, are described by means of external morphology using histological sections, and have been characterized by the ITS-1 molecular marker. The study of molecular markers such as ITS-1 is proposed as a powerful technique for identification at the species level in terrestrial planarians.
\end{abstract}

\section{Introduction}

Terrestrial planarians (Tricladida: Terricola) constitute a poorly understood group of free-living flatworms containing somewhat over eight hundred species of flat or cylindrical animals, 4-600 $\mathrm{mm}$ in length. Current taxonomy recognizes three families: Bipaliidae, Geoplanidae, and Rhynchodemidae. The Rhynchodemidae comprise several small species with an elongated and more or less cylindrical body, with a rounded or truncated anterior end and a single pair of eyes situated anteriorly. This family is cosmopolitan, and widely distributed throughout Europe, where two subfamilies (Rhynchodeminae and Microplaninae) have been reported (see Minelli, 1974; 1977; Ball \& Reynoldson, 1981). A review of the American species of the family can be found in Ball \& Sluys (1990).

Data from terrestrial planarians of the Iberian Peninsula are scarce, and to our knowledge the introduced bipaliid Bipalium kewense Moseley, 1878 is the only species reported so far (FilellaSubirà, 1983). In contrast, the rhynchodemid $M i$ croplana terrestris (O. F. Müller, 1774) is widely distributed throughout Europe, and has been found in Menorca (Balearic Islands) (Minelli, 1974; 1977), while Microplana pyrenaica (Von Graff, 1899) has been described from the French Pyrenees.

The systematics of the land planarians, as that of the entire Tricladida, is very difficult because they usually lack clear external diagnostic characters. Thus, an exhaustive microscopical analysis of the internal anatomy with emphasis on the copulatory apparatus is always needed for identification at the species level. Although almost all of the land planarians are hermaphroditic, the male and female systems are not necessarily present at the same stage of development in a given individual, and isolated descriptions of proterandrous and proterogynous individuals may well be one of the causes of the present taxonomic confusion (Ball \& Sluys, 1990). Moreover, immature organisms lack the copulatory apparatus, thus preventing unequivocal identification.

Lately, based on the generally accepted hy- 
pothesis that phenotypic similarities between individuals of the same species are a reflection of a correspondingly similar genotype, some molecular markers have been developed as speciesspecific markers or diagnostic characters (see e.g., DeSalle \& Birstein, 1996). These molecular markers have proved to be invaluable when dealing with zoological groups where species identification is a challenge for systematists (Carranza, 1997). In describing relationships among different organisms, molecular systematists also employ the comparative method, which involves direct or indirect information on nucleic acid and protein sequences of related species.

Ribosomal DNA (rDNA) plays a pivotal role in the protein synthesis machinery of all prokaryotic and eukaryotic cells. The eukaryotic rDNA array typically consists of several hundred tandemly repeated copies of the transcription unit, separated by nontranscribed spacers (NTS). The transcription unit codes for the $18 \mathrm{~S}, 5.8 \mathrm{~S}$ and $28 \mathrm{~S}$ genes and for external and internal transcribed spacers (ETS, ITS-1 and ITS-2) (for a review, see Long \& Dawid, 1980). The multiple copies of this cluster appear to be nearly identical within a given organism (Hillis \& Dixon, 1991; Lane et al., 1985). This conservation of the sequence presumably reflects functional constraints on the molecules, which are required for optimal translational efficiency. This process of homogenization is called concerted evolution (Dover, 1982; Hillis \& Dixon, 1991). The ITS-1 (internal transcribed spacer) is located between the nucleat ribosomal $18 \mathrm{~S}$ and the $5.8 \mathrm{~S}$ genes. Sequences of the ITS-1 segment in invertebrates have been reported for the coastal North American tiger beetle Cicindela dorsalis (Vogler \& DeSalle, 1994), several dipteran species (Schlöttlerer et al., 1994; Miller et al., 1996; Tang et al., 1996), and the freshwater turbellarians of the Dugesia gonocephala species complex (Carranza, 1997).

In the present work we report the finding of two species of terrestrial planarians of the family Rhynchodemidae in the northeastern part of the Iberian Peninsula, one species being new to science. These are the first records for this family in the Iberian Peninsula. Amplification of the ITS-1 region is proposed as an easy and accessible tool for species differentiation and even identification within the genus Microplana.

\section{Material and methods}

Terrestrial planarians were collected from beneath stones lying in moist areas in two different localities of the northeastern part of the Iberian Peninsula (Fig. 1). Specimens were taken to the laboratory, reared in small capsules at $4^{\circ} \mathrm{C}$, and recorded with a VHS video-recorder connected to a stereo-microscope. In addition, some specimens of these two populations were studied at the histological level, and their nucleic acids extracted in order to analyze inter- and intra-specific length variability in the ITS1 locus.

For histological studies, specimens were fixed in Steinmann's fluid ( 1 part distilled water, 1 part concentrated nitric acid, 1 part $5 \%$ sodium chloride in saturated mercuric chloride) for four minutes and transferred to $70 \%$ ethanol. Fixed specimens were processed to paraffin blocks, and $8 \mathrm{~mm}$ thin sagittal sections were obtained. Sections were stained in haematoxylin/ eosin.

The ITS-1 locus was amplified for two individuals of Microplana terrestris ("Font Groga" population) and for two individuals of Microplana nana sp. nov. ("Les Alberes" population). High-molecular weight genomic DNA from single individuals was purified according to a modification of the guanidine isothiocyanate method initially described for RNA by Chirgwin et al. (1979). ITS-1 was amplified using primers 9F (5'-GTAGGTGAACCTGCGGAAGG-3') and ITSR (5'TGCGTTCAAATTGTCAAT-3'), which were designed to

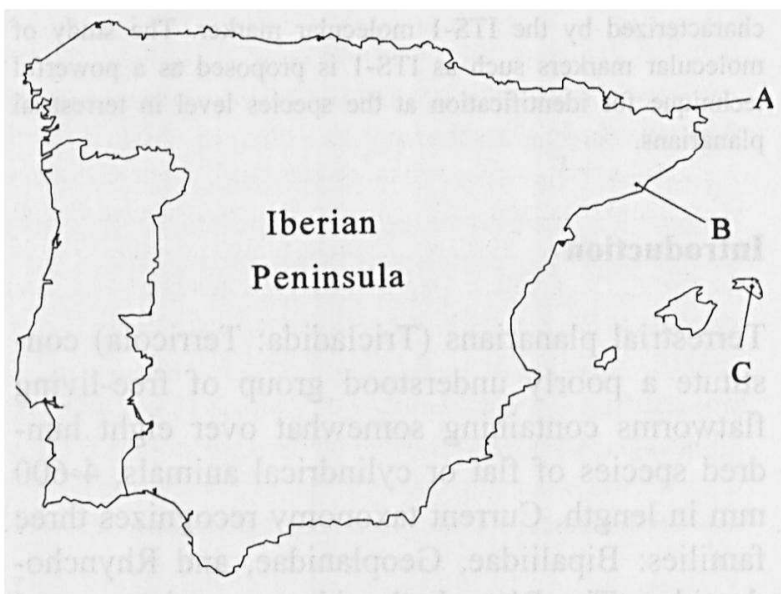

Fig. 1. Map of the Iberian Peninsula with sampling localities of terrestrial planarians. Capital letters refer to the "Coll de Banyuls" site at Les Alberes (A) and "Font Groga" and "La Rierada" sites at Massis de Collserola (B). C refers to literature-cited specimens of $M$. terrestris from Menorca (Balearic Islands). 
match the $3^{\prime}$ end of the 18S rDNA gene and the 5 ' of the $5.8 \mathrm{~S}$ rDNA gene, respectively. Amplification was carried out in a 50 $\mu \mathrm{l}$ volume reaction: $80^{\prime} \mathrm{ng}$ of genomic DNA, 0.6 units of DynaZyme ${ }^{\mathrm{TM}}$ polymerase, $200 \mu \mathrm{M}$ of dNTP's and $0.5 \mathrm{mM}$ of each primer were used for the PCR reaction. The PCR program consisted of a first denaturing step of $3 \mathrm{~min}$ at $94^{\circ} \mathrm{C}$; and $30 \mathrm{sec}$ at $94^{\circ} \mathrm{C}, 30 \mathrm{sec}$ at $50^{\circ} \mathrm{C}, 30 \mathrm{sec}$ at $72^{\circ} \mathrm{C}, 35 \mathrm{cycles}$. An aliquot of the reaction was analyzed by electrophoresis on a $1.5 \%$ agarose gel and visualized with ethidium bromide.

\section{Results}

Seventeen specimens of cylindrical terrestrial planarians assigned to the family Rhynchodemidae have been collected from two localities in the northeastern part of the Iberian Peninsula. Two species, assigned to the genus Microplana, have been identified through the study of histological sections of the specimens.

\section{Systematic section}

Family Rhynchodemidae Von Graff, 1896

Subfamily Microplaninae Pantin, 1953

Genus Microplana Vejdovsky, 1890

\section{Microplana nana sp. nov. (Figs. 2-8)}

Type material. - Holotype, sagittal sections of 1 specimen mounted on 3 slides stained with hematoxylin-eosin, BMNH catalogue number 1998.2.9.1; Les Alberes (Girona, Spain), "Coll de Banyuls", February 7th, 1997 (E. Mateos \& S. Carranza leg.). Paratype, sagittal sections of 1 specimen mounted on 2 slides stained with hematoxylin-eosin, labeled BMNH catalogue number 1998.2.9.2, same locality and date, 1997 (E. Mateos \& S. Carranza leg.). The type material has been deposited at the Natural History Museum, London.

Type locality. - "Coll de Banyuls" at Les Alberes (Rabós d'Empordà, Girona, Spain), coordinates UTM 31 TEH0400.

Material examined. - Four specimens, type locality, February 7th, 1997 (E. Mateos \& S. Carranza leg.): two specimens for histology, two specimens for nucleic acids extraction.

Video-recording. - A 90 seconds video of one specimen of Microplana nana was recorded during locomotion, with details on the movement of the head. This video was digitalized and saved as mnana.mov in quick time format. The mnana.mov

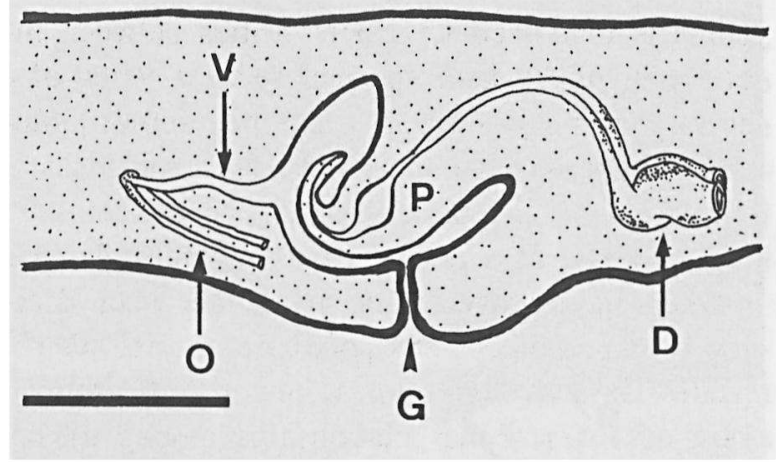

Fig. 2. Microplana nana sp. nov.: sagittal reconstruction of the copulatory apparatus, anterior part of the specimen towards the right, dorsal surface to the top and ventral surface to the bottom. Long conical penis papilla (P) with the anterior tip folded upwards. $\mathrm{G}=$ gonopore, $\mathrm{V}=$ female genital duct, $\mathrm{D}=$ vasa deferentia, $\mathrm{O}=$ oviducts (scale bar $400 \mu \mathrm{m}$ ).

file is available from the anonymous ftp site: porthos.bio.ub.es/ pub/incoming; it can be easily visualized in a Macintosh or in a PC computer.

Habitat. - Specimens were found under stones in a shady area near a running water course, on a holm oak (Quercus ilex), and in riverside woodlands.

Etymology. - The specific epithet nana refers to the short body length of the four adult specimens found: $4 \mathrm{~mm}$ for sectioned specimens and up to $10 \mathrm{~mm}$ for fully stretched living specimens.

Diagnosis. - Very small adult individuals $(4 \mathrm{~mm}$ in fixed specimens and $10 \mathrm{~mm}$ in fully stretched living specimens); long conical penis papilla; testes situated ventrally from behind the ovaries to the pharyngeal region; absence of the following structures: seminal vesicle, bursa copulatrix, genito-intestinal duct, and well-developed penis bulb.

Description. - Fully stretched living specimens are about $8-10 \mathrm{~mm}$ long and $0.5 \mathrm{~mm}$ wide, while the two fixed specimens measured up to $4 \times 0.7$ $\mathrm{mm}$. The mouth is set at $2.5 \mathrm{~mm}$ and the genital aperture at $3 \mathrm{~mm}$ behind the anterior tip of the body. The small ocelli are located at the anterior end; the dorsal surface is greyish with darker spots all over the surface; anterior end darker; creeping sole white. 

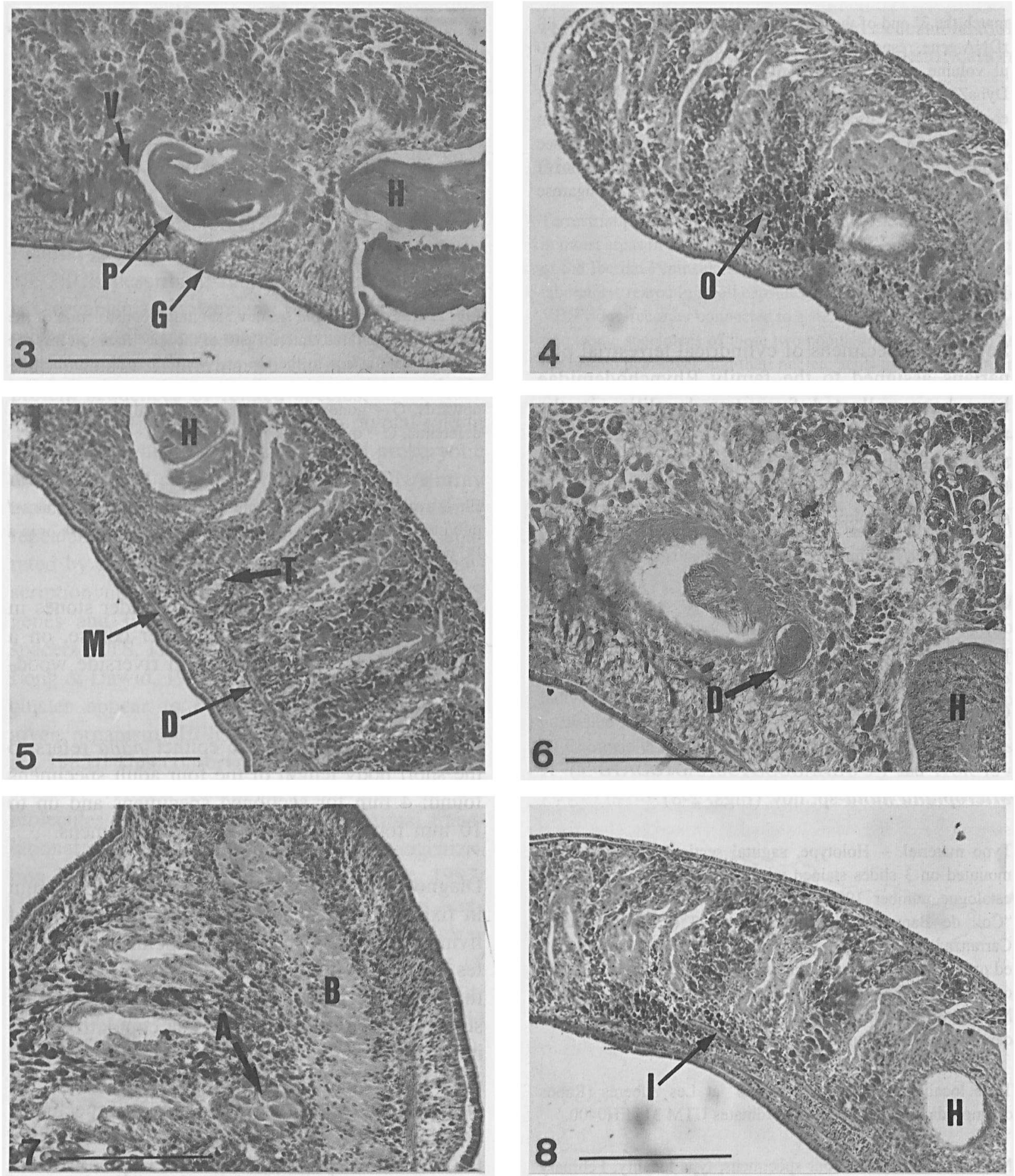

Figs. 3-8. Microplana nana sp. nov.: 3, sagittal section illustrating the presence of a long conical penis papilla with the anterior tip folded upwards $(\mathrm{P})$, the gonopore $(\mathrm{G})$, the very narrow female genital duct $(\mathrm{V})$, and the pharynx $(\mathrm{H})$. Note the absence of seminal vesicle and bursa copulatrix. Anterior part of the specimen towards the right, dorsal surface to the top and ventral surface to the bottom (scale bar $400 \mu \mathrm{m}, \mathrm{BMNH}$ catalogue number 1998.2.9.2); 4, sagittal section illustrating one of the two oviduct openings (O). Anterior part of the specimen towards the right, dorsal surface to the top and ventral surface to the bottom (scale bar $400 \mu \mathrm{m}, \mathrm{BMNH}$ catalogue number 1998.2.9.1); 5, sagittal section illustrating one of the two vasa deferentia (D) receiving the openings of some testes on the way 
Epidermis and musculature. - The epidermis of the creeping sole is about $10 \mu \mathrm{m}$ thick, its cilia are densely packed and about $3 \mu \mathrm{m}$ long. The epidermis of the lateral and the dorsal body wall is about $15 \mu \mathrm{m}$ thick and its cells are packaged with rhabdites that have the same height as the epidermal cells. Nuclei of the epidermal cells are between 5-7 $\mu \mathrm{m}$ in diameter and basal to central in the cells.

In the ventral part of the body, interior to the subepidermal circular and longitudinal muscle layers, and separated from these by a layer of parenchymal tissue, there is a well-developed layer of longitudinal parenchymal muscles about $15 \mathrm{~mm}$ thick. This parenchymal muscle layer occurs only ventrally (Fig. 5).

Nervous system. - The central nervous system consists of two large ventral nerve cords connected by several commissures lying between the parenchymal muscle layers and the vasa deferentia. These nerve cords fuse at the anterior part of the body.

Alimentary system. - The anterior ramus of the intestine runs forwards to within about $0.1 \mathrm{~mm}$ of the anterior tip of the animal, giving off several pairs of branched lateral diverticula. Both posterior rami extend to almost the hind end, each giving off several diverticula. The diverticula are lined with large columnar cells each about 100 $\mu \mathrm{m}$ long.

In the holotype, the pharynx is about $0.5 \mathrm{~mm}$ long and $0.35 \mathrm{~mm}$ in diameter. It is externally lined by a ciliated epithelium $4 \mu \mathrm{m}$ thick, the cilia being $2 \mu \mathrm{m}$ long. This epithelium covers a longitudinal muscle layer of about $2 \mu \mathrm{m}$ thick, followed by a $4 \mu \mathrm{m}$ thick layer of circular muscle, a layer $100 \mu \mathrm{m}$ thick of parenchymal tissue with glandular elements, and a layer about $12 \mu \mathrm{m}$ thick of circular and longitudinal muscle fibers. This is bounded internally by a non-ciliated epithelium 6 $\mu \mathrm{m}$ thick.
Male reproductive system (Fig. 2). - Each of the approximately 10 pairs of testes (Fig. 5) is oval to circular, about $100 \mu \mathrm{m}$ in diameter. The testes are situated ventrally, dorsal to the nerve cords, extending from behind the ovaries to the pharyngeal region. The testes discharge medially and ventrally into the vasa deferentia (Fig. 5).

The vasa deferentia are two visible ducts situated ventrally, lateral and slightly dorsal to each nerve cord, receiving on the way to the penis papilla the openings of some testes (Fig. 5). Before entering the penis papilla, the vasa deferentia enlarge to form two independent false seminal vesicles (Fig. 6), hereafter the vasa deferentia narrow again and at the base of the penis papilla they fuse to form the ejaculatory duct, the latter lined with a nucleated epithelium. Some expansions can be observed along the ejaculatory duct due to the aecumulation of spermatozoa (Fig. 3).

The penis papilla is a well-developed, long, conical structure consisting of loose tissue surrounded by circular and longitudinal muscle layers. The penial bulb is weakly muscular. The gonopore is situated ventrally and centrally to the atrium (Fig. 3).

Female reproductive stystem (Fig. 2). - The two ovaries are oval-shaped, about $125 \mu \mathrm{m}$ high by $100 \mu \mathrm{m}$, and lie ventrally above the brain at about $0.3 \mathrm{~mm}$ from the anterior end of the animal (Fig. 7). The oviducts run posteriorly just above the nerve cords to the level of the narrow female genital duct (Fig. 3), opening independently into the latter (Fig. 4). The oviducts give rise to numerous short, dorsal branches that are in contact with the vitellaria. The vitellaria are well developed and extend from the level of the ovaries towards the posterior end of the animal and fill much of the space between the intestinal branches. The cells of the vitellaria are large, vacuolated and with glandular cytoplasm. The

$\leftarrow$

to the penis papilla $(\mathrm{T})$, the well-developed layer of longitudinal parenchymal muscles $(\mathrm{M})$, and the pharynx $(\mathrm{H})$. Anterior part of the specimen to the bottom, dorsal surface to the right and ventral surface to the left (scale bar $400 \mu \mathrm{m}$, BMNH catalogue number 1998.2.9.1); 6, sagittal section illustrating one of the two enlargements of the vasa deferentia (D) at the base of the penis papilla; pharynx $(\mathrm{H})$. Anterior part of the specimen towards the right, dorsal surface to the top and ventral surface to the bottom (scale bar 200 $\mu \mathrm{m}, \mathrm{BMNH}$ catalogue number 1998.2.9.2); 7, sagittal section illustrating one of the ovaries (A) above the brain (B). Anterior part of the specimen to the top, dorsal surface to the left and ventral surface to the right (scale bar $200 \mu \mathrm{m}, \mathrm{BMNH}$ catalogue number 1998.2.9.1); 8, sagittal section illustrating one of the two oviducts $(\mathrm{I})$. Anterior part of the specimen to the right, dorsal surface to the top and ventral surface to the bottom (scale bar $400 \mu \mathrm{m}$, BMNH catalogue number 1998.2.9.1). 
oviducts are ciliated internally and have an external diameter of about $18 \mu \mathrm{m}$.

The female genital duct (Fig. 8) is about $25 \mu \mathrm{m}$ in diameter and $300 \mu \mathrm{m}$ long and is lined with a $5 \mu \mathrm{m}$ thick non-ciliated epithelium. The genital duct is surrounded by few muscle fibers and many glands.

Remarks. - The previously known European species of Microplana differ from $M$, nana in the following traits. M. pyrenaica (Von Graff, 1899): bigger size $(50 \mathrm{~mm})$; presence of genito-intestinal duct and seminal vesicle; smaller penis papilla. M. scharffi (Von Graff, 1899): bigger size (30 $\mathrm{mm}$ ); presence of genito-intestinal duct and seminal vesicle. M. giustii Minelli, 1977: testes placed between the pharynx and the genital atrium; presence of genito-intestinal duct. $M$. henrici Bendl, 1908: presence of folds in the genital atrium; presence of genito-intestinal duct; striped habitus of the animal. M. terrestris (O.F. Müller, 1774): bigger size (up to $26 \mathrm{~mm}$ ); presence of bursa copulatrix, genito-intestinal duct and seminal vesicle; penial bulb well developed. $M$. humicola Vejdovsky, 1890: presence of seminal vesicle; smaller penial papilla; the female genital duct runs upwards to the dorsal part of the body and not backwards as in $M$. nana. $M$. mahnerti Minelli, 1977: presence of a large seminal vesicle and bursa copulatrix.

Microplana perereca Marcus \& Marcus, 1959, is similar to $M$. nana in the general structure of the copulatory apparatus. Nevertheless, the bigger size and diameter of $M$. perereca (the sectioned animal was $13 \mathrm{~mm}$ long and $1.5 \mathrm{~mm}$ in diameter), the presence of a well-developed penial bulb, the absence of two independent enlargements (false seminal vesicles) in the vasa deferentia before they fuse at the base of the penis papilla, and its particular geographical distribution (São Miguel, Azores) suggests that $M$. nana and $M$. perereca are different species.

Microplana styriacus (Freisling, 1935) differs from $M$. nana in the presence of a copulatory bursa and a very large and highly musculated penial bulb. This species was described on a single specimen from Austria that was destroyed during the Second World War. Later on, and based on the similarities of the different structures of the copulatory apparatus, Minelli (1977) synonymized $M$. styriacus with $M$. terrestris.

Microplana terrestris (O.F. Müller, 1774) (Figs. 9-13)

Material examined. - "Font Groga" at Massis de Collserola (Sant Cugat del Vallès, Barcelona, Spain), coordinates UTM 31TDF2687: 1 specimen June 5th, 1996 (E. Mateos leg.); 3 specimens June 11th, 1996 (E. Mateos leg.); 2 specimens February 12th, 1997 (E. Mateos leg.); 2 specimens February 13th, 1997 (F. Mateos leg.); 4 specimens February 19th, 1997 (E. Mateos leg.). Two specimens used for nucleic acids extraction and 3 specimens for histology. The slides containing the histological sections have been deposited at the Natural History Museum, London (U.K.) under BMNH catalogue numbers 1998.2.9.3-5.

Habitat. - Specimens were found under stones in a shady area near an intermittent running water course, on an oak-ash woodland containing holm oak (Quercus ilex), pedunculate oak (Quercus robur), ash (Fraxinus excelsior), elm (Ulmus sp.), water willow (Salix sp.), and white poplar (Populus alba). Some introduced tree species such as plane (Platanus sp.), black poplar (Populus nigra), acacia (Acacia sp.), and sycamore (Acer pseudoplatanus) occur as well. The predominant species of the undergrowth are horsetails (Equisetum telmateia) and soft shield ferns (Polystichum seritiferum).

Description. - We will only detail some relevant features of this well-known species. Fully stretched living specimens are between 10 and 26 $\mathrm{mm}$ long; the fixed animals measured up to $15 \times$ $1 \mathrm{~mm}$. The body is cylindrical, becoming narrower towards the anterior end. The two tiny ocelli, placed in unpigmented areas, are situated near the anterior tip. The dorsal surface is reddish to brown with black granules all over the surface; anterior end darker; creeping sole white. There are several testes situated ventrally from behind the ovaries to the pharyngeal region. The penis bulb and the conical penis papilla are well developed (Fig. 9) and a large seminal vesicle is present (Fig. 9). The two vasa deferentia, with notable expansions due to sperm accumulation, 

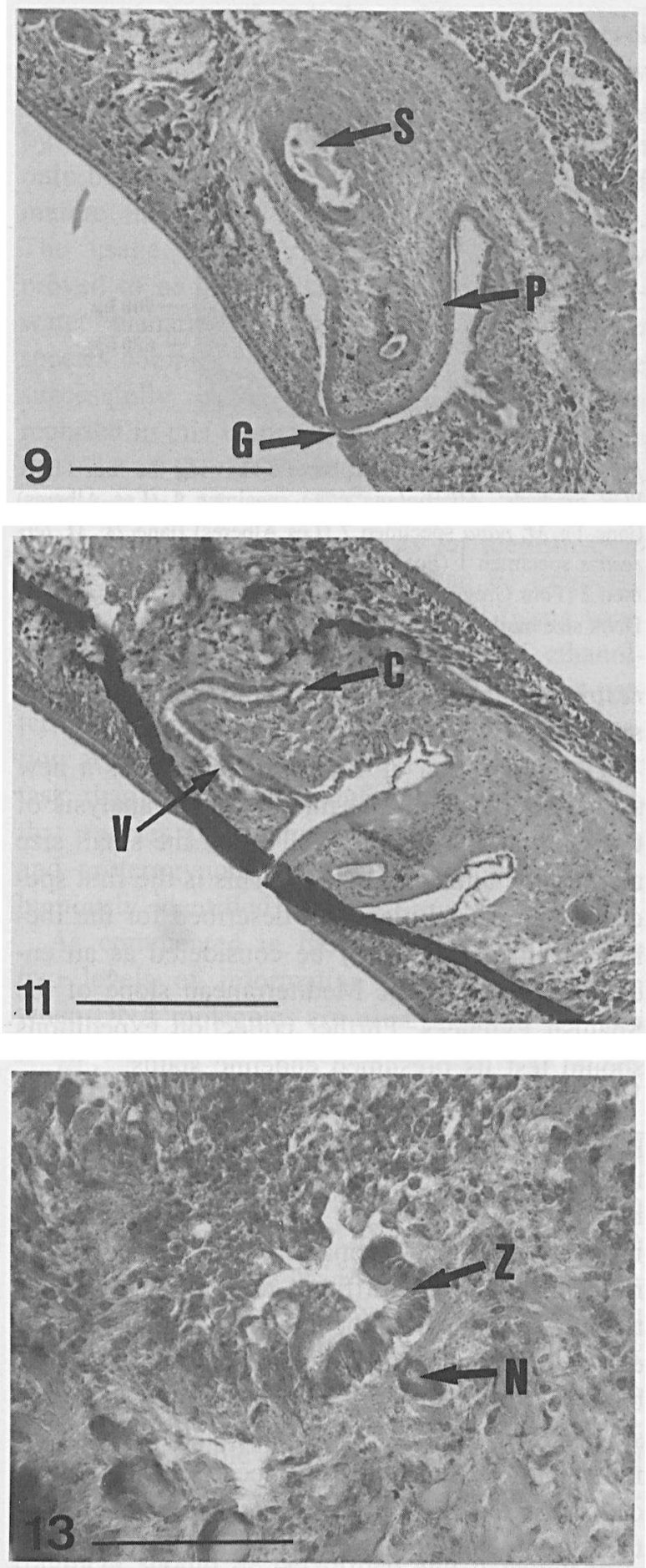
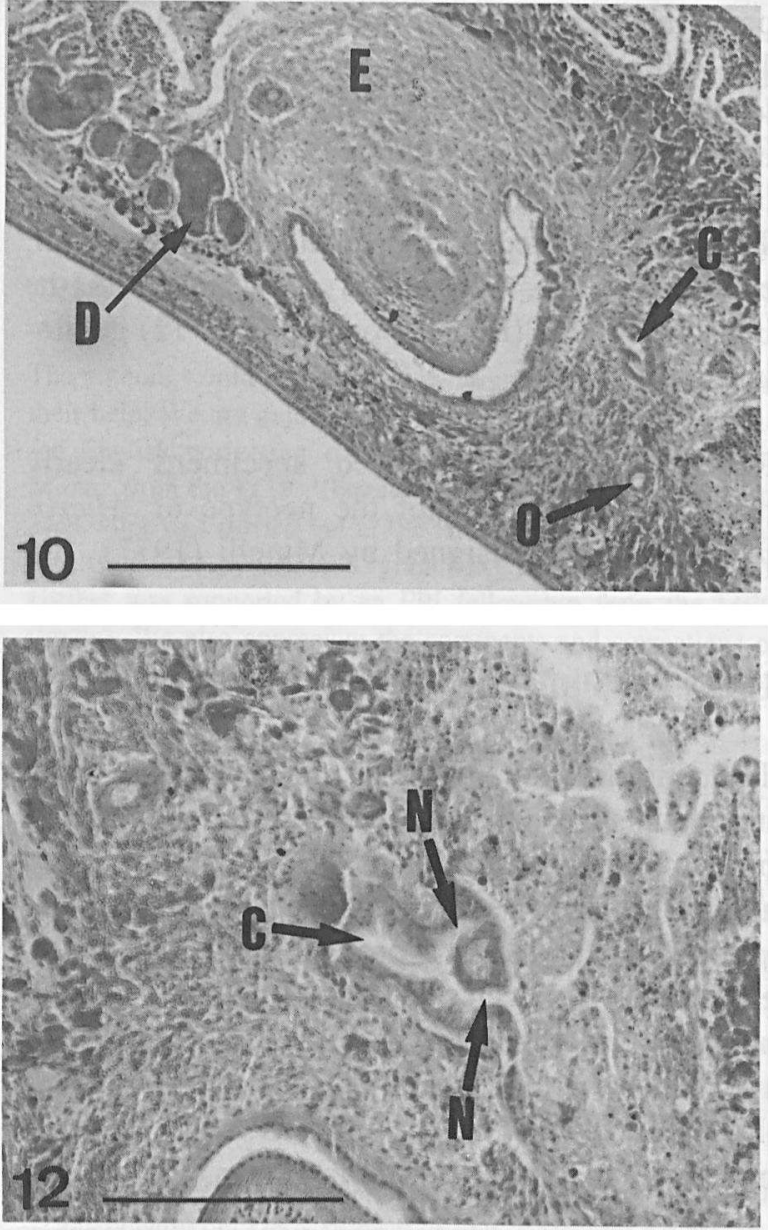

Figs. 9-13. Microplana terrestris (from Font Groga): 9, sagittal section illustrating the long conical penis papilla $(P)$, the seminal vesicle (S) and the gonopore (G). Anterior part of the specimen towards the right, dorsal surface to the top and ventral surface to the bottom (scale bar $400 \mu \mathrm{m}, \mathrm{BMNH}$ catalogue number 1998.2.9.3); 10, sagittal section illustrating the enlarged vasa deferentia (D), the oviduct opening (O), the bursa copulatrix $(C)$ and the penis bulb $(E)$. Anterior part of the specimen towards the right, dorsal surface to the top and ventral surface to the bottom (scale bar $400 \mu \mathrm{m}, \mathrm{BMNH}$ catalogue number 1998.2.9.3); 11, sagittal section illustrating the female genital duct (V) and the bursa copulatrix (C). Anterior part of the body towards the right, dorsal surface to the top and ventral surface to the bottom. Note that this section is folded at the bottom of the specimen (scale bar $400 \mu \mathrm{m}, \mathrm{BMNH}$ catalogue number 1998.2.9.5); 12, sagittal section illustrating

the ciliated bursa copulatrix $(\mathrm{C})$ and the two genito-intestinal "ducts $(\mathrm{N})$. Anterior part of the body to the bottom, dorsal surface to the right and ventral surface to the left (scale bar $200 \mu \mathrm{m}$, BMNH catalogue number 1998.2.9.4); 13, sagittal section illustrating the genitointestinal duct $(\mathrm{N})$ and a detail of the ciliated epithelium $(\mathrm{Z})$ in the intestine-bursa copulatrix contact zone. Anterior part of the specimen towards the top, dorsal surface to the left and ventral surface to the right (scale bar $100 \mu \mathrm{m}, \mathrm{BMNH}$ catalogue number 1998.2.9.5). 
open independently in the seminal vesicle (Fig. 10). The oviducts run from the ovaries to the level of the female genital duct where they open independently (Fig. 10). The female genital duct is connected with the bursa copulatrix (Fig. 11). The bursa is lined with a ciliated, non-glandular, epithelium (Fig. 12) and is connected with the intestine by one (Fig. 13) or two (Fig. 12) genitointestinal ducts.

Remarks. - The sectioned specimens clearly match the description of the neotype of Microplana terrestris designed by Minelli (1977).

\section{ITS-1 Amplification}

The amplification of the ITS-l locus from both individuals of Microplana terrestris yielded a product band size of about $900 \mathrm{bp}$, while it sized about $650 \mathrm{bp}$ for both individuals of Microplana nana (Fig. 14). Such a product band size difference clearly indicates that $M$. terrestris and $M$. nana are differentiated from a molecular point of view and, therefore, differences in the length of the ITS-1 region may be used as a species-level molecular marker in land planarians.

\section{General discussion}

Data on terrestrial planarians in Europe have been summarized by Minelli (1977), according to whom the genus Microplana is represented by! a total of 7 species. From these species, only $M i$ croplana terrestris is widely distributed throughout Europe (see review in Minelli, 1977; Ball \& Reynoldson, 1981) and North America (Hyman, 1939; Ogren, 1984; 1991). The North American representatives most probably have been introduced from Europe (Ball \& Sluys, 1990). M. terrestris has also been recorded in Madeira (De Beauchamp, 1957; Marcus \& Marcus, 1959). Thus, the finding of specimens of $M$. terrestris in the Iberian Peninsula is not surprising due to their widespread distribution in the Mediterranean area. Nevertheless, the identification of our specimens is not unequivocal, since the $M$. ter-

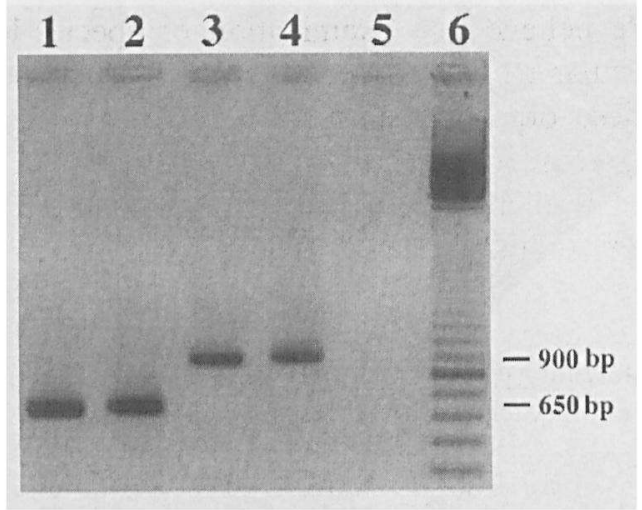

Fig. 14. Agarose gel electrophoresis showing the four ITS-1 PCR products: Microplana nana specimen 1 (Les Alberes) (lane 1); $M$. nana specimen 2 (Les Alberes) (lane 2); $M$. terrestris specimen 1 (Font Groga) (lane 3); $M$. terrestris specimen 2 (Font Groga) (lane 4); negative control (lane 5); 100 bp DNA size marker (lane 6).

restris group may consist of more than a single species (Minelli, 1977).

The description of Microplana nana as a new species is based on the microscopical analysis of the internal anatomy as well as on the small size attained by adult individuals. This is the first species of terrestrial planarian described for the Iberian Peninsula and may be considered as an endemic species of the Mediterranean slope of the Spanish Pyrenees. Further collection expeditions should test its presumed endemic status.

Identification at the species level of terrestrial planarians belonging to the Rhynchodemidae is not an easy task and must be done by means of histological study of the full anatomy, emphasizing the copulatory apparatus. Furthermore, the rhynchodemids are difficult to sort out by traditional histological studies, mainly because apparent morphological differences between taxa may be very small. Very often, they are almost impossible to identify unless the material is very well fixed. Other difficulties at species level identification are the existence of proterandrous and proterogynous individuals, and the lack of sexual organs in immature animals (Jones et al., 1990). All together this led to the currently poorly understood systematics of the group, as evidenced by the numerous synonymized species within the Rhynchodemidae (see Minelli, 1977; Ball \& Sluys, 1990). 
We believe that examination of species-level molecular markers, could be helpful in the study of these organisms that are difficult to identify by external or internal morphology and that can only be reliably identified by using characters of mature individuals (i.e., the genital apparatus). The usage of molecular markers has already proved to be very useful in analyzing the freshwater planarians of the Dugesia gonocephala species complex (Carranza, 1997). It can also be successfully applied to terrestrial planarians, as reported in this work on the basis of difference in the size of the ITS-1 PCR product between $M$. terrestris and $M$. nana. ITS amplification can also be used for juvenile, as well as for identification of live specimens, since DNA can be extracted and PCR amplified from very small tissue samples removed from either alive or $100 \%$ ethanolfixed organisms. Thus, once the PCR product pattern for each species would be defined, identification at the species level would be a much easier task than histological studies are nowadays, so that species (including immature, proterandrous and proterogynous individuals) could be unambiguously identified.

As commented in the introduction, there are two levels of information that we can obtain when DNA molecules are used in taxonomy: one is the size of the molecule and the other is the DNA sequence itself. In our example, the ITS-1 PCR product of two individuals, previously assigned to $M$. terrestris by means of morphological analysis of the copulatory apparatus, is $250 \mathrm{bp}$ longer than the ITS-1 PCR product of the two individuals described as $M$. nana. This large difference in size of the ITS-1 fragment between individuals of $M$. terrestris and $M$. nana strongly indicates that the assignment of the four individuals to two different species is correct. Nevertheless, it is possible that different species of land planarians exhibit the same ITS-1 product pattern. If it is the case, sequencing of the ITS-1 fragment should be performed and it would provide a higher resolution to differentiate between species. Considering that ITS- 1 is part of the rDNA eukaryotic array (see introduction), the individuals belonging to the same species should have an identical ITS-1 DNA sequence (or very similar), while individuals belonging to different species should have a different ITS-1 sequence due to the genetic differentiation processes that occur subsequently to reproductive isolation by speciation.

\section{Acknowledgements}

The authors would like to thank J. Baguña and M. Riutort for their help. We are indebted to $G$. Marfany for discussions and for English correction of the manuscript and to Asuncion Muñoz from the I.C.F., Barcelona for the video digitalization. This work was carried out at the laboratory of J. Baguñâ, and was supported by a CIRIT grant GRQ93-1044 (to J.B.). G. Girribet was supported by an FPI fellowship from the MEC (Spain). We also appreciate the comments and corrections of two anonymous referees that clearly improved this manuscript.

\section{References}

Ball, I.R. \& T.B. Reynoldson, 1981. British planarians: 1141 (Cambridge University Press, Cambridge).

Ball, I.R. \& R. Sluys, 1990. Turbellariax Tricladida: Terricola. In: D. Dindal (ed), Soil biology guide: 136-153 (John Wiley \& Sons, New York).

Beauchamp, P. de, 1957. Planaires terrestres. Mission du C.N.R.S. à Madère 1957 (2). Bull. Soc. zool. Fr., 82: 357360.

Carranza, S., 1997. Taxonomia molecular mitjançant la seqũenciació del DNA ribosòmic 18S. Aplicació a l'origen i filogênia dels Platihelmints. PhD thesis, Universitat de Barcelona, Barcelona, Spain.

Chirgwin, J.M., A.E. Przybyla, R.J. MacDonald \& W.J. Rutter, 1979. Isolation of biologically active ribonucleic acid from sources enriched in ribonuclease. Biochemistry, 18: 5294-5299.

DeSalle, R. \& V.J. Birstein, 1996. PCR identification of black caviar. Nature, 381: 197-198.

Dover, G.A., 1982. Molecular drive: a cohesive model of species evolution. Nature, 299: 111-117.

Filella-Subirà, E., 1983. Nota sobre la presència de la planària terrestre Bipalium kewense Moseley, 1878 a Catalunya. Butll. Inst. catal. Hîst. nat., 49: 151.

Hillis, D.M. \& M.T. Dixon, 1991. Ribosomal DNA: molecular evolution and phylogenetic inference. Quart. Rev. Biol., 66: 411-453.

Hyman, I.H., 1939. New species of flatworms from North, Central, and South America. Proc. U.S. natn. Mus, 86: 419-439.

Jones, H.D., J.P.E.C. Darlington \& R.M. Newson, 1990. A new species of land planarian preying on termites in Kenya (Platyhelminthes: Turbellaria: Tricladida: Terricola). J. Zool., Lond., 220: 249-256.

Lane, D., B. Pace, G.L. Olsen, D.A. Stahl, M.I. Sogin \& N.R. 
Pace, 1985. Rapid determination of 16S ribosomal RNA sequences for phylogenetic analyses. Proc. natn. Acad. Sci. U.S.A., 82: 6955-6959.

Long, E.O. \& I.B. Dawid, 1980. Repeated genes in eukaryotes. Annu. Rev. Biochem., 49: 727-764.

Marcus, E. \& E. Marcus, 1959. Turbellaria from Madeira and the Azores. Boletim Mus. munic. Funchal, 12: 15-42.

Miller, B.R., M.B. Crabtree \& H.M. Savage, 1996. Phylogeny of fourteen Culex mosquito species, including the Culex pipiens complex, inferred from the internal transcribed spacers of ribosomal DNA. Insect molec. Biol., 5: 93-107.

Mínelli, A., 1974. Primi reperti di planarie terrestri autoctone in Italia con descrizione di Geobenazzia tyrrhenica n. gen., n. sp. Mem. Mus. civ. St. nat. Verona, 20: 535548.

Minelli, A, 1977. A taxonomic review of the terrestrial planarians of Europe. Boll. Zool., 44: 399-419.
Ogren, R.E, 1984. The land planarian Microplana terrestris (Platyhelminthes: Turbellaria) from the United States. Trans. Am. microsc. Soc., 103: 130-136.

Ogren, R.F. 1991. Land planarians from Ontario and Quebec. Trans. Am. microsc. Soc., 110: 27-36.

Schlöttlerer, C., M.T. Hauser, A. von Haeseler \& D. Tautz, 1994. Comparative evolutionary analysis of rDNA ITS regions in Drosophila. Mol. Biol. Evol., 11: 513-522.

Tang, J., L. Toe, C. Back \& T.R. Unnasch, 1996. Intraspecific heterogeneity of the rDNA internal transcribed spacer in the Simulium damnosum (Diptera: Simuliidae) complex. Mol. Bíol. Evol., 13: 244-252.

Vogler, A.P. \& R. DeSalle, 1994. Evolution and phylogenetic information content of the ITS-1 region in the tiger beetle Cicindella dorsalis. Mol. Biol. Evol., 11× 393405.

Received: 15 August 1997 